\title{
Evaluation of bull semen fertility by homologous in vitro fertilization tests
}

\author{
B Marquant-Le Guienne 1*, P Humblot 1, M Thibier 1, \\ C Thibault 2 \\ 1 UNCEIA - Services Techniques, 13, rue Jouët, BP 65-94703 Maisons-Alfort; \\ 2 INRA, Physiologie Animale, 78350 Jouy-en-Josas, France
}

(Received 7 July 1989; accepted 26 January 1990)

\begin{abstract}
Summary - In vitro fertilization assays were performed to investigate their validity in evaluating artificial insemination (Al) bull fertility. A total of 1532 oocytes, collected from ovaries at the abattoir, were subsequently used in a $4 \times 6 \times 2$ factorial design: 4 doses of heparin added into the capacitation and fertilization medium $(0 ; 0.05 ; 0.1$ and $0.2 \mu \mathrm{g} / \mathrm{ml}), 6$ different bulls with known on-field nonreturn (NR) rates (range: $64.6-75.3 \%$ ) and 2 different ejaculates for each bull, collected within a approximately 1 -month interval. Oocytes were considered fertilized when 2 pronuclei (or more) were seen in the ooplasm. Both the heparin dose and bull exerted a highly significant effect on the in vitro fertilization (IVF) rates which ranged, per oocyte group, from 30-80\%; bull $x$ dose of heparin interaction was significant $(P<0.001)$. The $0.05 \mu \mathrm{g} / \mathrm{ml}$ dose of heparin was optimal for discriminating individual bulls. At that dose, the correlation coefficients between the bulls, NR rates and the IVF rates from each ejaculate (within-bull or the mean of two ejaculates), were highly significant $(r=0.83)$. The rates of polyspermy were also significantly influenced by bull and heparin dose, but there was no interaction. In conclusion, capacitation and fertilization in a modified Tyrode medium containing 0.05 $\mu \mathrm{g} / \mathrm{ml}$ of heparin may be a valuable tool for evaluating Al bull fertility.
\end{abstract}

\section{in vitro fertilization / heparine / bull fertility}

Résumé - Evaluation de la fertilité du sperme de taureau par fécondation in vitro homologue. Un test de fécondation in vitro a été mis au point pour tenter d'évaluer la fertilité des taureaux utilisés en insémination artificielle. Un total de 1532 ovocytes bovins ont été prélevés sur des ovaires provenant d'abattoirs et utilisés dans une expérience multifactorielle $: 4$ doses d'héparine différentes $(0 ; 0,05 ; 0,1$ et $0,2 \mu \mathrm{g} / \mathrm{ml})$ ont été ajoutées dans le milieu de fécondation, le sperme de 6 taureaux différents de fertilité connue a été utilisé pour la fécondation (taux de non-retour allant de 64,6 à 75,3\%). Pour chaque taureau 2 éjaculats différents ont été étudiés (les 2 ejaculats avaient été collectés à 1 mois d'intervalle environ). Les ovocytes étaient considérés comme fécondés quand 2 pronuclei (ou plus) étaient visibles dans l'ooplasme. L'effet de la dose d'héparine ainsi que du taureau sur la fécondation in vitro étaient hautement significatifs avec des taux de fécondation variant de 30 à $80 \%$ selon les groupes d'ovocytes. L'interaction taureaux/dose était hautement significative ( $\mathrm{P}<0,001$ ). La dose de $0,05 \mu \mathrm{g}$ d'héparine/ml semble optimale pour discriminer les taureaux. A cette concentration le coefficient de correlation entre le pourcentage de fécondation in vitro et le taux de non retour est hautement significatif $(r=0,83)$. Le taux de polyspermie est également influencé de manière significative par le taureau ainsi que par la dose d'héparine mais il n'est pas relié au taux de non retour. II semble donc que l'addition d'une dose de $0,05 \mu \mathrm{g} / \mathrm{m} / \mathrm{d}$ 'héparine dans le milieu de fécondation permette une évaluation de la fertilité des taureaux.

\section{fécondation in vitro / héparine / fertilité des taureaux}

\footnotetext{
* Correspondence and reprints
} 


\section{INTRODUCTION}

Classical parameters of sperm evaluation are inadequate to predict male fertility (Boyd et al, 1973; Goffaux, 1978) unless several parameters are combined together (Wood et al, 1986). The heterologous penetration of hamster oocytes has often been used to predict sperm fertility, but no correlation has been clearly established for human (Junca et al, 1982; Margalioth et al, 1983) and for bull (Thibault, 1989) sperm.

It was hypothesized that homologous in vitro fertilization (IVF) techniques could be used for the evaluation, and perhaps the prediction, of individual artificial insemination (AI) bull fertility (Thibier, 1984). Zona-intact homologous oocytes are now used to test all steps of sperm penetration and the further development of the eggs (Gandolfi and Moor, 1987; Fukui et al, 1988). Various studies (Marks and Ax, 1985; Graham and Foote, 1987; Lenz et al, 1988) are consistent with this possibility, but require confirmation in a more realistic system prior to eventually being launched in the $\mathrm{Al}$ industry. With frozen semen capacitated with heparin, high in vitro fertilization rates can be repeatedly achieved (Parrish et al, 1986; Le Guienne et al, 1988; Leibfried-Rutledge et al, 1989).

The purpose of this study was to investigate the relationship between in vitro fertilization rates, when using different heparin concentrations, and the non-return rates of bulls of known fertility.

\section{MATERIAL AND METHODS}

\section{Oocyte recovery}

Ovaries were obtained from a slaughter house and transported to the laboratory within $2 \mathrm{~h}$ in a phosphate-buffered saline at $35^{\circ} \mathrm{C}$. Cumulus oocyte complexes (COCS) were aspirated from $1-5-\mathrm{mm}$ antral follicles and washed 3 times in tissue culture medium 199 (TCM 199) buffered with $25 \mathrm{mM}$ Hepes and supplemented with 10\% of heat-treated oestrous cow serum (ECS). Granulosa cells contained in follicular fluid were washed 3 times in the same medium. A total number of 1767 oocytes were studied. From those, 1532 were used to assess bull fertility; the 235 remaining oocytes were only fixed to control the maturation stage.

\section{In vitro maturation}

For in vitro maturation, we used either $\mathrm{B} 2$ medium (INRA, Ménézo) supplemented with $20 \%$ ECS, or B2 supplemented with $20 \%$ fetal calf serum (FCS) and $10 \mu \mathrm{g} \mathrm{FSH/LH}$ plus $1 \mu \mathrm{g} / \mathrm{ml} \mathrm{E2}$ $17 \beta$. COCS were cultured in $0.7 \mathrm{ml}$ of maturation medium in NUNC 4-cell multi-dishes in the presence of 1 to $5 \times 10^{6}$ granulosa cells per $\mathrm{ml}$. The oocytes were incubated at $38.5^{\circ} \mathrm{C}$ under $5 \% \mathrm{CO}_{2}$ in air atmosphere for $26 \mathrm{~h}$.

\section{Fertility of the bulls studied}

The 6 bulls used in this study originated from a Regional Union of Al Cooperatives of western France. Field non-return rates 60-90 d after $\mathrm{Al}$ were recorded for 2 consecutive years. Total number of Al's per bull varied from 802 to 88008 . The bull effect on this variable was found to be highly significant $(P<0.0005)$ and the bulls non-return rates (weighted means) varied from 64.6 (bull 1) to $75.3 \%$ (bull 6 ). No bull per year interaction was found. Consequently, mean non-return rates were used when studying the relationship between field fertility rates and in vitro fertilization rates.

\section{Capacitation and fertilization}

Two different ejaculates, collected at intervals of approximately 1 month, were tested twice each in the in vitro fertilization system. Modified Tyrode's media (TALP) were used for capacitation and fertilization (Ball et al, 1983; Parrish et al, 1986). For each replicate, 2 French straws $(0.25$ 
$\mathrm{mi}$ ) of the same ejaculate were thawed and motile sperm that swam up were separated, as previously described (Parrish et al, 1986). After $1 \mathrm{~h}$ at $38.5^{\circ} \mathrm{C}$, the upper fraction containing $6-8 \times$ $10^{6} \mathrm{Spz}$ was centrifuged and the motility of the sperm determined; spermatozoa were suspended to a final concentration of $1 \times 10^{6}$ cells $/ \mathrm{ml}$ in the fertilization medium without further sperm incubation.

A final volume of $0.5 \mathrm{ml}$ of sperm suspension was distributed in 4 groups of test tubes containing $0 ; 0.05 ; 0.1$ or $0.2 \mu \mathrm{g} / \mathrm{ml}$ of heparin. The matured oocytes were washed 3 times in TALP. Ten were transferred to each fertilization test tube. The gametes were cultured under $5 \% \mathrm{CO}_{2}$ in air for $18 \mathrm{~h}$ at $38.5^{\circ} \mathrm{C}$.

The oocytes were then fixed for $24 \mathrm{~h}$ in acetic alcohol ( $1 \mathrm{~V} / 3 \mathrm{~V})$ and subsequently stained with $1 \%$ acetoorcein for examination under a light microscope at x. 250 and x. 500 Oocytes were recorded as fertilized when 2 pronuclei could be seen in the cytoplasm.

\section{Statistical analysis}

The main effects of year and bull on field nonreturn rates and the techniques of oocytes culture on the rate of maturation were investigated by analysis of variance adapted for proportions with unequal frequency (Gabriel, 1963), and by
Chi 2 analysis. Interactions between the 2 factors were studied by the method described by Goodman (1964).

Main effects of the bull, ejaculate within-bull and the dose of heparin, and corresponding interactions on IVF and polyspermy rates were studied by non-orthogonal analysis of variance by the MODLI program (Kobilinsky, 1980).

Variance components associated to the bull and ejaculate (within-bull) were subsequently estimated for each dose of heparin by a 2-stage hierarchical analysis of variance (Dagnelie, 1984).

\section{RESULTS}

After $26 \mathrm{~h}$ of maturation in B2 medium supplemented with ECS, $90 \%$ of the oocytes reached the $M$ II stage (838/932). This mean rate was not significantly different $(P>0.05$ ) from that (88\%: $727 / 835)$ observed in oocytes matured in the presence of FCS, gonadotropins and oestradiol added to the B2 medium. Similarly, cumulus expansion did seem very similar in the 2 media and, accordingly, the results from these 2 maturation procedures were pooled.

Table 1. Effect of different doses of heparin on in vitro fertilization rate among 6 bulls. "Percentage of fertilized eggs (mean of 2 replicates for 2 different ejaculates). $n=$ number of inseminated oocytes. Bull effect $P<0.001$; Ejaculate within bull $P<0.001$; Dose $P<0.001$; Bull $\times$ Dose interaction $P<0.001$.

\begin{tabular}{|c|c|c|c|c|c|c|c|c|}
\hline \multirow{3}{*}{$\begin{array}{c}\text { Bull } \\
1\end{array}$} & \multicolumn{8}{|c|}{ Heparin doses $(\mu \mathrm{i} / \mathrm{mi})$} \\
\hline & \multicolumn{2}{|c|}{0} & \multicolumn{2}{|c|}{0.05} & \multicolumn{2}{|c|}{0.1} & \multicolumn{2}{|c|}{0.2} \\
\hline & $42.5^{\star}$ & $(54)$ & 35.5 & (62) & 45.6 & $(57)$ & 50.8 & $(63)$ \\
\hline 2 & 30.7 & (75) & 38.6 & (83) & 36.8 & (87) & 47.4 & (78) \\
\hline 3 & 42.9 & (63) & 40.0 & (70) & 58.1 & (62) & 75.0 & (56) \\
\hline 4 & 30.7 & (75) & 51.3 & (74) & 55.4 & (56) & 54.1 & (61) \\
\hline 5 & 35.2 & (54) & 58.1 & (62) & 75.8 & (62) & 69.4 & (59) \\
\hline 6 & 70.6 & (51) & 74.5 & (55) & 74.6 & (59) & 87.0 & (54) \\
\hline Means* & $40.6 \pm$ & $5(372)$ & $48.5=$ & $5(406)$ & 56.4 & $5(383)$ & 62.5 & (371) \\
\hline
\end{tabular}


The in vitro fertilization rates according to doses of heparin and bull are given in table I. The overall variation expressed by its extreme values was $30.7-87.0 \%$. Without heparin, the fertilization rates were less than $45 \%$ for all bulls, except one. Increasing doses of heparin resulted in enhanced fertilization rates for all bulls $(P<0.01)$, but the magnitude of this enhancement varied according to the bull (bull $x$ dose interaction; $P<0.001$ ). The extremes of this variation between no heparin and $0.2 \mu \mathrm{g} / \mathrm{ml}$ were seen for bulls 1 and 5 , showing an increase of 8 and 34 points, respectively, of fertilization rates. These observations were consistent with a large overall bull effect on these IVF rates $(P<0.001)$ and response to doses of heparin.

The respective influence of the bulls and the ejaculates within heparin doses is given in table II. For the 3 lowest doses of heparin, including none, the bull effect was highly significant. The variance component associated to the bull was very similar for the 4 doses tested. No ejaculate effect was found to be significant for none or $0.05 \mu \mathrm{g} / \mathrm{ml}$ of heparin, contrary to the 2 higher doses, for which a significant effect of the ejaculate was found, indicating a less consistent mean rate of within-bull fertilization with 0.1 and $0.2 \mu \mathrm{g} / \mathrm{ml}$ of heparin in the media.

The matrix of the correlation coefficients shown in table III, illustrates the relationship between in vitro fertilization rates at the various doses tested, and those with the on-field non-return rates.

The coefficients of correlations were high $(r=0.9)$ for the IVF rates of the 2 ejaculates at the 2 lowest doses, but were non-significant at 0.1 and $0.2 \mu \mathrm{g} / \mathrm{ml}$. Similarly, at these 2 high levels, none of the IVF rates were correlated with the NR rates, whatever ejaculates or means of the 2 were considered. With no heparin added to the IVF medium, the IVF rates were also not correlated with the NR rates $(P>0.05)$. Finally, IVF rates for $E 2$ and $M(E 1 E 2)$ were significantly correlated $(P<0.05)$ with the individual NR of each bull. Additionally, the significance of the correlation between IVF rate for $E 1$ and non-return rate, was not far from the 0.05 level (table IV). Figure 1 illustrates the regression line between on-field NR rates and IVF rates (mean of 2 ejaculates) for this dose.

The effects of increasing doses of heparin on the polyspermy rate were recorded for each assay (table IV). The mean rate varied from 1.3 (no heparin) to $8.2 \%(0.2$

Table II. Bull and ejaculate effects and associated variance components ( $\mathrm{b}, \mathrm{s}$ e) on in vitro fertilization rates at different doses of heparin $(\mu \mathrm{g} / \mathrm{ml}) .{ }^{* * *} P<0.001 ;{ }^{* \star *} P<0.005 ;{ }^{\star *} P<0.01 ; \mathrm{NS}=$ Non-significant.

\begin{tabular}{|c|c|c|c|c|}
\hline \multirow{2}{*}{$\begin{array}{l}\text { Variance } \\
\text { components }\end{array}$} & \multicolumn{4}{|c|}{ Heparin doses $(\mu g / m l)$} \\
\hline & 0 & 0.05 & 0.1 & 0.2 \\
\hline$s^{2} b$ & $\underset{\star \star \star \star \star}{0.024}$ & 0.020 & 0.023 & $\underset{* \star}{0.022}$ \\
\hline$s^{2} e$ & $\begin{array}{c}0 \\
\text { NS }\end{array}$ & $\begin{array}{c}0.0008 \\
\text { NS }\end{array}$ & $\underset{\star \star}{0.009}$ & $\underset{* \pi *}{0.013}$ \\
\hline$s^{2} r$ & 0.014 & 0.015 & 0.005 & 0.005 \\
\hline
\end{tabular}


Table III. Correlation coefficients between IVF rates for each ejaculate (E1, E2) or the mean (M[E1, E2]) and field NR rates (FNR). ${ }^{* *} P<0.01$; $P<.05 ; x P<0.07$; NS $=$ Non significant.

\begin{tabular}{lcccc}
\hline Heparin doses $(\mathrm{ug} / \mathrm{ml})$ & 0 & 0.05 & 0.1 & 0.2 \\
\hline E1/E2 & 0.96 & 0.92 & 0.60 & 0.75 \\
& $* *$ & NS & NS \\
E1/FNR & 0.39 & 0.78 & 0.17 & 0.20 \\
& $N S$ & $x$ & NS & NS \\
E2/FNR & 0.62 & 0.86 & 0.81 & 0.71 \\
& NS & $*$ & $x$ & NS \\
M [E1,E2]/FNR & 0.47 & 0.83 & 0.52 & 0.47 \\
& NS & $*$ & NS & NS \\
\hline
\end{tabular}

$\mu \mathrm{g} / \mathrm{ml})$, but no relationship between bull polyspermic rates and NR rates, was significant at any dose of heparin tested.

\section{DISCUSSION}

The mean maturation rate achieved in this experiment with 1532 oocytes, was about $90 \%$ and consistent with previous reports
(Leibfried-Rutledge et al, 1989). It shows that our in vitro conditions (with or without gonadotropin and oestradiol) both seemed to be quite efficient, and allowed us to investigate if there was a relation between in vitro fertilization and NR rates.

The fertilization rates were assessed by visualization of 2 or 3 (polyspermy) pronuclei in the ooplasm. The first striking feature was that both the dose of heparin and

Table IV. Effect of doses of heparin on the rate of polyspermy of in vitro fertilized bovine oocytes. " percentage of polyspermic eggs. $n=$ number of fertilized eggs. Bull effect $P<0.05$; Dose effect $P<$ 0.05 ; Bull and dose interaction NS.

Heparin doses $(\mu g / m l)$
Bull
0.05
0.1
0.2

$\begin{array}{lllllrlrr}1 & 4.3^{*} & (23) & 9.1 & (22) & 3.8 & (26) & 3.1 & (32) \\ 2 & 0 & (23) & 4.5 & (32) & 4.5 & (32) & 2.7 & (37) \\ 3 & 3.7 & (27) & 7.1 & (28) & 16.7 & (36) & 11.9 & (42) \\ 4 & 0 & (23) & 3.6 & (38) & 6.4 & (31) & 3.0 & (33) \\ 5 & 0 & (19) & 7.7 & (36) & 4.2 & (47) & 7.3 & (41) \\ 6 & 0 & (36) & 9.7 & (41) & 11.4 & (44) & 21.3 & (47) \\ \text { Mean* }^{*} & 1.3 \pm 0.8(151) & 6.5 \pm 1.6(197) & 7.8 \pm 1.8(216) & 8.2 \pm 1.8 & (232)\end{array}$






Fig 1. Regression line between field non-return rates and IVF rates with $0.05 \mu \mathrm{g} / \mathrm{ml}$ heparine $(y=0.22$ $x+0.58 ; r=0.83 ; P<0.01)$.

the bull exerted a major influence on in vitro fertilization rates and that there was a significant interaction of these 2 factors.

The influence of individual bulls on in vitro fertilization rates has also been reported by Ongoda et al (1987), Aoyagi et al (1988) Niwa and Ohgoda (1988). Without heparin, in vitro fertilization rates differed according to the bull, but they were not correlated with the non-return rates. By contrast, with $0.05 \mu \mathrm{g} / \mathrm{ml}$ of heparin, there was a significant correlation between IVF and NR rates. Moreover, the differences between bulls were amplified in vitro.

An important fact of the present study is the interaction between these 2 factors. In terms of IVF rates, individual bulls did not react in the same manner to the highest doses of heparin, indicating that the discrimination between individuals depended upon the concentration of the glycosaminoglycan in the fertilization medium. This was further demonstrated by the nonsignificant effect of bulls within the $0.2 \mu \mathrm{g} /$ $\mathrm{ml}$ dose, conversely to what was seen for the lower doses. To our knowledge, this major observation has not been previously reported.

From a practical standpoint, it is necessary, as a first step, to determine the optimal dose of heparin, which results in a non-significant effect of the ejaculate, together with the significant influence of the bull. The results of analysis of the various components of the variance-covariance matrix indicate that only the 0 and $0.05 \mu \mathrm{g} /$ $\mathrm{ml}$ doses met those requirements. Increasing the dose of heparin resulted in higher IVF rates, but at higher doses, bull differences in fertilizing ability were lower due to specific dose response relationship for each individual.

In relation with the consistent data obtained with $0.05 \mu \mathrm{g} / \mathrm{ml}$ dose of heparin, it may be argued that although the number of bulls was low, those bulls well characterised by their non-return rates calculated on large number of Al's, are representative of the animal population within this precise $\mathrm{Al}$ stud. Effectively, their non-return rates are 
in the range of the whole population (Humblot, 1986). The fact that these inseminations were performed from ejaculates which did not necessarily include those that were tested here in vitro, gives an even greater value to the significant relationship with the IVF rates of both ejaculates tested in vitro or of their mean, and suggests that it is possible to use IVF test to determine individual bull fertilizing ability. It may be speculated that the correlation between IVF rates and NR rates would be higher if this NR rate was obtained after Al's performed with these precise ejaculates. These 2 ejaculates per bull were collected at close intervals of time, that was done on purpose to be sure in a first step, that non major and unknown detrimental effects on the breeding soundness of the bulls had occurred in the meantime. Tests with longer intervals between semen collection are currently under investigation.

Heparin enhanced the rates of polyspermy and this may be relevant to the interaction of glycosaminoglycans with the acrosome reaction (Ax and Lenz, 1987). Our results show that the rates of polyspermic fertilization did not give more information than IVF rate variations. Although these rates were significantly affected by the bulls, there was no interaction between doses and individuals.

In conclusion, this study shows that the addition of $0.05 \mu \mathrm{g} / \mathrm{ml}$ of heparin to the in vitro fertilization medium, resulted in a within-bull in vitro fertilization rate which is related to in vivo fertility rate assessed by the non-return rate. If confirmed on a larger number of young bulls, such an in vitro test would be valuable in evaluating the level of fertility of Al bulls before they are used on the field.

\section{ACKNOWLEDGMENTS}

The authors gratefully acknowledge the help of $\mathrm{Mr}$ Gendron, Director of the Al Center of Mayenne, and his collaborator Mr Le Pecheux. They would also like to thank Mrs F Le Gal and $J$ Nahon for their technical assistance, as well as Mrs A Daifuku for her assistance in the English translation.

\section{REFERENCES}

Aoyagi $Y$, Fujii $K$, Iwazumi $Y$, Furudate $M$, Fukui $Y$, Ono $H(1988)$ Effects of two treatments of semen from different bulls on in vitro fertilization results of bovine oocytes. Theriogenology 30, 973-985

Ax RL, Lenz RW (1987) Glycosaminoglycans as probes to monitor differences in fertility of bulls. J Dairy Sci 70, 1477-1486

Ball GD, Leibfried ML, Lenz EW, Ax RL, Bavister BD, First NL (1983) Factors affecting successful in vitro fertilization of bovine follicular oocytes. Biol Reprod 28, 717-725

Boyd LJ, Smith GF, Wood PDP, Craven JA (1973) Fertility of inseminations with 2 sperm concentrations in œestrus synchronised cattle. Anim Prod 17, 163-168

Dagnelie $P$ (1984) Théorie et méthodes statistiques. Presses Agronomiques de Gembloux 2, $463 \mathrm{pp}$

Fukui Y, Glew AM, Gandolfi F, Moor RM (1988) Ram specific effects on in vitro fertilization and clevage of sheep oocytes matured in vitro. J Reprod Fertil 82, 337-340

Gabriel KR (1963) Analysis of variance of proportions with unequal frequencies. $J$ Anim Stat Assoc 58, 1133-1157

Gandolfi F, Moor RM (1987) Stimulation of early embryonic development in the sheep by coculture with oviduct epithelial cells. J Reprod Fert 81, 23-28

Goffaux M (1978) Choix de l'éjaculat. Etude des possibilités d'amélioration du taux de nonretours moyen du centre d'insémination artificielle par une sélection supplémentaire des 
taureaux ou des éjaculats. Elev Insem 165, 17-20

Goodman $L$ (1964) Simple methods for analyzing three factors interaction in contingency tables. J Am Stat Assoc 59, 319-352

Graham JK, Foote RH (1987) Dilaurylphosphatodylcholine liposome effects on the acrosome reaction and in vitro penetration of zone-free hamster eggs by bull sperm. II. A fertility assay for frozen-thawed semen. Gamete Res 16, 147-158

Humblot (1986) La mortalité embryonnaire chez les bovins. In: Epidemiologie de la Fertilité (Henry-Suchet J, Mintz M, Spira A eds) SFEF Masson, Paris, 213-242

Junca AM, Mandelbaum J, Plachot $M$, de Grouchy J (1982) Evaluation de la fécondance du sperme humain par la fécondation in vitro inter-spécifique. Ann Génét 25, 92-95

Kobilinsky A (1980) Software for the treatment of the linear model on a municomputer. Proc in Computational Statistics (Compstat 1980). Physical-Verlag Wien, 167-173

Le Guienne B, Thibault C, Chupin D, Gerard M, Thibier M (1988) Fécondation in vitro chez les mammifères domestiques. Etat actuel et perspectives. Elev Insem 225, 13-22

Leibfried-Rutledge ML, Critser ES, Parrish JJ, First NL (1989) In vitro maturation and fertilization of bovine oocytes. Theriogenology 31 , 61-74

Lenz RW, Martin JL, Bellin ME, Ax RL (1988) Predicting fertility of dairy bulls by inducing acrosome reactions in sperm with chondroitin sulfate. J Dairy Sci 71, 1 073-1 077

Margalioth ET, Laufer N, Navot D, Voss R, Schenker JG (1983) Reduced fertilization ability of zone free hamster ova by spermatozoa from male partners of infertile couples. Arch Androl 10, 67-71

Marks JL, Ax RL (1985) Relationship of non return rates of dairy bulls to binding affinity of heparin to sperm. J Dairy Sci 68, 2 078-1 082

Niwa K, Ohgoda O (1988) Synergic effect of caffein and heparin on in vitro fertilization of cattle oocytes matured in culture. Theriogenology 30, 733-741

Ohgoda $O$, Niwa K, Yuhara M, Takahashi S, Kanoya K (1987) Variations in penetration rates in vitro of follicular oocytes do not reflect conception rates after artificial insemination using frozen semen from different bulls. Theriogenology 29, 1 375-1 381

Parrish JJ, Susko-Parrish JL, Leibfried-Rutledge ML, Critser ES, Eyestone WH, First NL (1986) Bovine in vitro fertilization with frozenthawed semen. Theriogenology 25, 591-600

Thibault C (1990) La culture de l'œuf fécondé des mammifères. In: Actual gynécol $20^{\circ}$ série, Masson, Paris, 33-43

Thibier M (1984) UNCEIA Annual Report UNCEIA, Paris, 14

Wood PDP, Foulkes JA, Shaw RC, Melrose DR (1986) Semen assessment fertility and the selection of Hereford bulls for use in A I. J Reprod Fertil 76, 783-795 